If that's what's required, that's what the United States will do."65 In mid-May, representatives of Maduro and Guaidó met for talks in Norway. ${ }^{66}$

\title{
The State Department Designates Iran's Islamic Revolutionary Guards Corps as a Foreign Terrorist Organization
}

doi:10.1017/ajil.2019.38

On April 8, 2019, President Trump announced that his administration would designate Iran's Islamic Revolutionary Guards Corps (IRGC) as a foreign terrorist organization (FTO) under Section 219 of the Immigration and Nationality Act (INA). ${ }^{1}$ This is the first time the United States has designated an arm of another government, rather than a non-state actor, as an FTO. ${ }^{2}$ In his announcement, Trump asserted that the Iranian government has used the IRGC to engage in a campaign of global terrorism. ${ }^{3}$ The measure, which officially took effect on April 15, expands on previous terrorism-related sanctions imposed on the IRGC and Iran. ${ }^{4}$

Under the INA, as amended in 1996 by the Antiterrorism and Effective Death Penalty Act, the Secretary of State can designate an organization as an FTO if:

(A) the organization is a foreign organization;

(B) the organization engages in terrorist activity ... or terrorism ...., or retains the capability and intent to engage in terrorist activity or terrorism; and

(C) the terrorist activity or terrorism of the organization threatens the security of United States nationals or the national security of the United States. ${ }^{5}$

${ }^{65}$ Interview with Maria Bartiromo of Mornings With Maria on Fox Business Network, Secretary of State, in Washington, DC (May 1, 2019), at https:/www.state.gov/interview-with-maria-bartiromo-of-mornings-withmaria-on-fox-business-network-4 [https://perma.cc/S8JE-JD4B].

${ }^{66}$ Rick Noack \& Terrence McCoy, Emissaries of Venezuela's Government, Opposition in Norway for Talks, Wash. Post (May 16, 2019), at https:/www.washingtonpost.com/world/venezuelan-government-and-opposition-reportedly-headed-to-norway-for-talks/2019/05/16/607ee77c-77b4-11e9-bd25-c989555e7766_story. html.

${ }^{1}$ Donald J. Trump, Statement on the United States Designation of Iran's Islamic Revolutionary Guard Corps as a Foreign Terrorist Organization, 2019 Daily Comp. Pres. Doc. No. 212 (Apr. 8) [hereinafter Trump Statement].

${ }^{2} I d$.

${ }^{3} \mathrm{Id}$.

${ }^{4}$ U.S. Dep't of State Press Release, Designation of the Islamic Revolutionary Guard Corps (Apr. 8, 2019), at https://www.state.gov/designation-of-the-islamic-revolutionary-guard-corps [https://perma.cc/GDA9-Q4M9] [hereinafter State Dep't Press Release]; see also In the Matter of the Designation of the Islamic Revolutionary Guard Corps (and Other Aliases) as a Foreign Terrorist Organization, 84 Fed. Reg. 15278 (Apr. 15, 2019) (promulgating the designation).

5 U.S.C $\$ 1189(a)(1)(2016)$ 
Designating an organization as an FTO has specified consequences:

(1) Unlawful conduct.-Whoever knowingly provides material support or resources to a foreign terrorist organization, or attempts or conspires to do so, shall be fined under this title or imprisoned not more than 20 years, or both, and, if the death of any person results, shall be imprisoned for any term of years or for life. . . .

(2) Financial institutions. - Except as authorized by the Secretary, any financial institution that becomes aware that it has possession of, or control over, any funds in which a foreign terrorist organization, or its agent, has an interest, shall-

(A) retain possession of, or maintain control over, such funds; and

(B) report to the Secretary the existence of such funds in accordance with regulations issued by the Secretary. ${ }^{6}$

The Treasury Department can also require that any U.S. financial institution in possession or control of an FTO's assets block all transactions involving those assets. ${ }^{7}$ In addition to the financial ramifications, representatives and members of an FTO are deemed inadmissible to enter the United States. ${ }^{8}$ According to the State Department, the designation "supports . . . efforts to curb terrorism financing and . . . encourage[s] other nations to do the same" and "[s] tigmatizes and isolates designated terrorist organizations internationally."

In determining whether to designate an entity as an FTO, the State Department looks to actual terrorist attacks executed by the organization in addition to deciding whether the group has planned future attacks or "retains the capability and intent to carry out such acts."10 Presently, over sixty organizations are designated as FTOs, including Al-Qaeda, Hamas, and Boko Haram. ${ }^{11}$

Unlike the other designated FTOs, the IRGC is part of a foreign government. Within the Iranian military, it "commands the Basij national militia that has internal security responsibilities, and the IRGC's Qods Force ... supports pro-Iranian movements and governments in the region." 12 No other official military organization of a foreign country has been designated an FTO. ${ }^{13}$

Trump noted the unprecedented nature of the measure but also explained that the IRGC has engaged in significant terrorist activity and terrorism:

618 U.S.C. $\$ 2339$ B(a) (2016). Material support means "any property, tangible or intangible, or service, including currency or monetary instruments or financial securities, financial services, lodging, training, expert advice or assistance, safehouses, false documentation or identification, communications equipment, facilities, weapons, lethal substances, explosives, personnel . ., and transportation, except medicine or religious materials." 18 U.S.C. $\$ 2239 \mathrm{~A}(\mathrm{~b})(1)$.

7 S U.S.C $\$ 1189(\mathrm{a})(2)(\mathrm{C})$.

${ }^{8} 8$ U.S.C $\$ 1182(\mathrm{a})(3)(\mathrm{B})(\mathrm{i})(\mathrm{IV})-(\mathrm{V})$.

${ }^{9}$ U.S. Dep't of State, Foreign Terrorist Organizations, at https://www.state.gov/foreign-terrorist-organizations [https://perma.cc/7B9U-2XYA].

${ }^{10} \mathrm{Id}$.

${ }^{11} \mathrm{Id}$.

12 Cong. Research Serv., IN11093, Iran's Revolutionary Guard Named a Terrorist Organization 2 (2019).

${ }^{13}$ Trump Statement, supra note 1. 
This unprecedented step, led by the Department of State, recognizes the reality that Iran is not only a state sponsor of terrorism, but that the IRGC actively participates in, finances, and promotes terrorism as a tool of statecraft. The IRGC is the Iranian Government's primary means of directing and implementing its global terrorist campaign.

This designation will be the first time that the United States has ever named a part of another government as [an] FTO. It underscores the fact that Iran's actions are fundamentally different from those of other governments. This action will significantly expand the scope and scale of our maximum pressure on the Iranian regime. It makes crystal clear the risks of conducting business with, or providing support to, the IRGC. If you are doing business with the IRGC, you will be bankrolling terrorism.

This action sends a clear message to Tehran that its support for terrorism has serious consequences. We will continue to increase financial pressure and raise the costs on the Iranian regime for its support of terrorist activity until it abandons its malign and outlaw behavior. ${ }^{14}$

In addition, the State Department charged that the IRGC "has been directly involved in terrorist plotting; its support for terrorism is foundational and institutional, and it has killed U.S. citizens." 15 The State Department's press release described the "Iranian regime" as "responsible for the deaths of at least 603 American service members in Iraq since 2003" and listed various terrorist activities dating back to 1996 which it attributed to the IRGC. ${ }^{16}$

This designation is the latest of many actions undertaken by the United States to penalize the IRGC and Iran for support of terrorism. In 2017, the Treasury Department designated the IRGC as a terrorism-supporting entity because of its relationship with the Qods Force. ${ }^{17}$ In prior years, other administrations had previously subjected the IRGC to sanctions due to its support of Iran's missile and nuclear programs and connection with Iran's human rights abuses. ${ }^{18}$ And since 1984, the State Department has branded Iran a "state sponsor of terrorism." 19 All of these measures have had the effect of imposing significant sanctions on the IRGC and its Qods Force. $^{20}$

Commentators have questioned whether the designation of the IRGC as an FTO will have any practical impact in view of these prior actions and other Iran-related sanctions. ${ }^{21}$

${ }^{14} I d$.

${ }^{15}$ State Dep't Press Release, supra note 4

${ }^{16} I d$.

${ }^{17}$ U.S. Dep't of Treasury Press Release, Treasury Designates the IRGC Under Terrorism Authority and Targets IRGC and Military Supporters Under Counter-Proliferation Authority (Oct. 13, 2017), at https://www.treasury. gov/press-center/press-releases/Pages/sm0177.aspx [https://perma.cc/5QCB-DGPG] [hereinafter Treasury 2017 Press Release]. The Qods Force had received a similar designation a decade earlier. U.S. Dep't of Treasury Press Release, Fact Sheet: Designation of Iranian Entities and Individuals for Proliferation Activities and Support for Terrorism (Oct. 25, 2007), at https://www.treasury.gov/press-center/press-releases/pages/hp644.aspx [https:// perma.cc/DF9G-LYG5].

${ }^{18}$ Treasury 2017 Press Release, supra note 17.

${ }^{19}$ U.S. Dep't of State, State Sponsors of Terrorism, at https://www.state.gov/state-sponsors-of-terrorism [https://perma.cc/CPZ8-ZNY5].

${ }^{20}$ State Dep't Press Release, supra note 4.

${ }^{21}$ See Elena Chachko, The U.S. Names the Iranian Revolutionary Guard a Terrorist Organization and Sanctions the International Criminal Court, LAWFARE (Apr. 10, 2019), at https://www.lawfareblog.com/us-names-iranianrevolutionary-guard-terrorist-organization-and-sanctions-international-criminal (explaining that existing measures are already a "powerful deterrent" and that any prosecutions pursuant to the designation may face significant 
The measure has also generated concerns about retaliatory actions from Iran and other countries. $^{22}$ Previous administrations hesitated in labeling the IRGC an FTO from concern that any designation would complicate U.S. operations in the region and lead other nations to target U.S. security agencies. ${ }^{23}$ High-level officials in the Trump administration reportedly opposed the designation due to these fears. ${ }^{24}$ After the announcement, Major General Mohammad Ali Jafari, commander of the IRGC, reportedly warned that U.S. troops stationed in the Middle East would lose "their current status of ease and serenity." 25 Soon after, Iran's Supreme National Security Council declared the U.S. Central Command a terrorist organization and Iranian President Hassan Rouhani followed up by signing a bill into law that officially designated it as a terrorist organization. ${ }^{26}$

The designation of the IRGC as an FTO comes amid escalating tensions between the United States and Iran. In the six months following the U.S. withdrawal from the Joint Comprehensive Plan of Action (JCPOA) in May 2018, the United States restored crippling sanctions - both primary and secondary-aimed at Iran. ${ }^{27}$ In the spring of 2019, the United States has cut out various exemptions to these sanctions ${ }^{28}$ and added still more sanctions targeting Iran's metal sectors. ${ }^{29}$ On May 8, 2019, Rouhani threatened to suspend aspects of

obstacles); Suzanne Maloney, What Both Trump and His Critics Get Wrong About the IRGC Terrorist Designation, LAWFARE (Apr. 18, 2019), at https://www.lawfareblog.com/what-both-trump-and-his-critics-get-wrong-aboutirgc-terrorist-designation (contending that "there is little reason to believe that [the designation] will prove a game-changer" but also conceding that the measure subjects individuals or entities to criminal prosecution); Afshon Ostovar, Designating Iranian Military Unit a "Terrorist Organization” Will Make U.S. Relations With Iran More Difficult. Here's How, WASH. POST (Apr. 8, 2019), at https://www.washingtonpost.com/politics/ 2019/04/08/designating-irgc-terrorist-organization-will-make-us-relations-with-iran-more-difficult-heres-how/? utm_term=.c1d4b7d02529 (asserting that the designation may not add much to prior pressures imposed on Iran and could potentially prompt countermeasures).

22 Ostovar, supra note 21.

${ }^{23}$ Amy Gearan \& Carol Morello, Trump to Designate Iranian Military Unit as a Terrorist Group, WASH. POST (Apr. 8, 2019), at https://www.washingtonpost.com/politics/trump-names-iranian-military-unit-as-a-terroristgroup/2019/04/08/1613f82e-5a01-11e9-842d-7d3ed7eb3957_story.html?utm_term=.e3be79749cb0.

${ }^{24}$ Edward Wong \& Eric Schmitt, Trump Designates Iran's Revolutionary Guards a Foreign Terrorist Group, N.Y. Times (Apr. 8, 2019), at https://www.nytimes.com/2019/04/08/world/middleeast/trump-iran-revolutionaryguard-corps.html.

${ }^{25}$ Deputy FM: US Strategic Mistake Against IRGC to Change Iranian Forces'Behavior Towards Americans, FARS News Agency (Apr. 9, 2019), at http://en.farsnews.com/13980120000227.

${ }^{26}$ Part 6: Iranian Officials React to IRGC Designation, IrAN PRIMER (Apr. 11, 2019), at https://iranprimer.usip. org/blog/2019/apr/09/part-6-iranian-officials-react-irgc-designation; Iran Designates as Terrorists All U.S. Troops in Middle East, ReuTERS (Apr. 30, 2019), at https://www.reuters.com/article/us-usa-iran-rouhani/iran-designatesas-terrorists-all-u-s-troops-in-middle-east-idUSKCN1S61GB. U.S. Central Command is the combatant command within the U.S. military that focuses on the Middle East.

27 See generally Jean Galbraith, Contemporary Practice of the United States, 113 AJIL 173 (2019) (providing a more detailed discussion of the re-imposition of sanctions and also discussing a case brought by Iran against the United States in the International Court of Justice (ICJ) in relation to these sanctions); Jean Galbraith, Contemporary Practice of the United States, 112 AJIL 514 (2018) (describing the U.S. withdrawal from the JCPOA).

${ }^{28}$ Michael Pompeo, U.S. Dep't of State, Decision on Imports of Iranian Oil (Apr. 22, 2019), at https://www. state.gov/decision-on-imports-of-iranian-oil [https://perma.cc/6SZT-M2BP] (announcing that the United States would no longer grant temporary exemptions from the re-imposition of sanctions).

${ }^{29}$ Exec. Order No. 13,871, 84 Fed. Reg. 20,761 (May 10, 2019). In another development in the spring of 2019, the ICJ ruled that it had jurisdiction over some claims in a case brought by Iran in 2016 challenging the U.S. use of Iranian assets to satisfy default judgments entered in U.S. domestic courts against Iran. Certain Iranian Assets (Iran v. U.S.), Judgment (Int'l Ct. Just. Feb. 13, 2019), available at https://www.icj-cij.org/files/caserelated/164/164-20190213-SUM-01-00-EN.pdf. 
Iran's compliance with the JCPOA, in which Iran had agreed to limit its nuclear program, if the country did not receive respite from sanctions within sixty days. ${ }^{30}$

\section{State Diplomatic and Consular Relations}

\section{United States Recognizes Israeli Sovereignty Over the Golan Heights}

doi:10.1017/ajil.2019.35

In a reversal of decades of U.S. foreign policy, on March 25, 2019, President Trump issued a presidential proclamation recognizing Israeli sovereignty over the Golan Heights, a strategic piece of territory captured by Israel from Syria during the Six-Day War in 1967. This move, which generated international criticism, is the latest in a series of actions by the Trump administration that advance the interests of the Israeli government.

On March 21, 2019, Trump tweeted that "[a]fter 52 years it is time for the United States to fully recognize Israel's Sovereignty over the Golan Heights, which is of critical strategic and security importance to the State of Israel and Regional Stability!"' In remarks later that day, Israeli Prime Minister Benjamin Netanyahu, joined by Secretary of State Mike Pompeo in Jerusalem, stated that:

President Trump has just made history. I called him. I thanked him on behalf of the people of Israel. He did it again. First he recognized Jerusalem as Israel's capital and moved the U.S. embassy here. Then he pulled out of the disastrous Iran treaty and re-imposed sanctions. But now he did something of equal historic importance. He recognized Israel's sovereignty over the Golan Heights, and he did so at a time when Iran is trying to use Syria as a platform to attack and destroy Israel. And the message that President Trump has given the world is that America stands by Israel. ${ }^{2}$

Four days later, Trump formalized his position by issuing a presidential proclamation declaring the new U.S. position on the status of the disputed territory. It reads, in part:

The State of Israel took control of the Golan Heights in 1967 to safeguard its security from external threats. Today, aggressive acts by Iran and terrorist groups, including

${ }^{30}$ Tamer El-Ghobashy, Michael Birnbaum \& Carol Morello, Iran Announces It Will Stop Complying With Parts of Landmark Nuclear Deal, WASH. PosT (May 8, 2019), at https://www.washingtonpost.com/world/iran-to-takesteps-to-reduce-its-commitment-to-landmark-nuclear-deal/2019/05/07/90cc3b1c-70fe-11e9-933130bc5836f48e_story.html?utm_term $=.525819244 \mathrm{bc} 3$.

${ }^{1}$ Donald J. Trump (@realDonaldTrump), TwiTTER (Mar. 21, 2019, 9:50 AM), at https://twitter.com/ realDonaldTrump/status/1108772952814899200?ref_src=twsrc\%5Etfw [https://perma.cc/4BQY-66CN].

${ }^{2}$ U.S. Dep't of State Press Release, Remarks with Israeli Prime Minister Benjamin Netanyahu Before Dinner (Mar. 21, 2019), at https://www.state.gov/secretary/remarks/2019/03/290554.htm [https://perma.cc/SX9A87GE]; Scott R. Anderson, Recognizing Israel's Claims to the Golan Heights: Trump's Decision in Perspective, LAWFARE (Mar. 22, 2019), at https://www.lawfareblog.com/recognizing-israels-claims-golan-heights-trumps-decision-perspective (observing that "[1] eft unclear [from Trump's tweet] was whether the president was merely calling for U.S. recognition ... or actually implementing it" and that "the first person to confirm the change in U.S. policy was none other than Israeli Prime Minister Benjamin Netanyahu”). 